\title{
A Preliminary Phyto-Pharmacognostical evaluation of Calotropis gigantea(L.) R. Br. (Alarka or Mandara ) Root.
}

\author{
Research Article
}

\author{
NeelimaSharma $^{1^{*}}$, Rama Shankar $^{2}$, Nitika Gupta $^{3}$, Pankaj Prakash $^{3}$ \\ 1. Research officer (Ayurveda) 2. Research officer (Botany) S-4 3. Research Scholar \\ National Vrkhayurveda research Institute, Gwalior Road, Jhansi.
}

\begin{abstract}
'Alarka' Calotropis gigantea (L.) R. Br. is a medicinal shrub, belongs to the family Asclepiadaceae. The plant is used in Ayurvedic system of medicine for healing various diseases. However the present study was aimed to evaluate the parameters to determine the identity, purity and strength of the plant. This study comprise of morphological, microscopical and preliminary phytochemical investigations of the shrub.
\end{abstract}

Key words : Asclepiadaceae, Pharmacognosy, Phytochemical screening, Calotropis gigantea (L.) R. Br .

\section{Introduction}

Calotropis gigantea (L.) R. Br. commonly known as milkweed or gigantic swallow wort is a common wasteland weed in India. Sanskrit name is 'Alarka', Swetarka or Mandara. In ancient Ayurvedic text it is commonly described as 'Alarka' $(1,2)$ with 'Arka' i. e. Calotropis procera (Ait) R. Br. But both are described to possess same medicinal properties, (2) as used to alleviate fevers, Rheumatism, indigestion, Elephantiasis, Asthma, Diarrhoea, or as analgesic(3, 5, 6). Milk, flowers, etc. possess medicinal properties but roots are especially described to possess medicinal value. Plant has many unique properties as the plant can survive in any type of soil. It is a drought tolerant plant also. It is not consumed by grazing animal(13). Along with the medicinal property it possess fungicidal and insecticidal properties(14) It is cultivated in South America for fibre production(15). Its latex is also reported to use for rubber production (16). It is also a hydrocarbon rich plant therefore may be explored for energy conservation(16). Therefore the plant Calotropis gigantea (L.) R. Br. possesses many other economic values along with medicinal importance.

Therefore in the present study standardization of Calotropis gigantea (L.) R. Br. roots has been done on pharmacognostic and phytochemical parameters.

\section{Aims and objective}

Recent literature review reveals that only a few work has been done regarding the pharmacognosy of

*Corresponding Author:

Neelima Sharma

Research officer (Ayurveda),

National Vrkhayurveda research Institute,

Gwalior Road, Jhansi

E-mail: drneelimasharmaayu@gmail.com the Calotropis gigantea (L.) R. Br. (18). Present study is different as it contains Macroscpic study, Microscopic study, phytochemistry, powder microscopy along with TLC. It is difficult to undertake systemic microscopical analysis due to their dried/broken stucture and analysis of large number of samples. Therefore, quick chemical tests of their main constituent or TLC fingerprinting is adopted for their true identity. Hence the present study with measurements of microscopic stuructures, powder microscopy and TLC will prove useful to researchers and professionals also. Therefore in the present study standardization of Calotropis gigantea (L.) R. Br. roots has been done on pharmacognostic and phytochemical parameters.

\section{Materials and Methods \\ Collection of Plant material and authentication}

Plant was collected from the pahuj dam area Jhansi in flowering stage and authenticated at NVARI Jhansi. The collected plant samples were washed under running fresh tap water to remove adherent soil and dirt. Three plant samples was collected, from the natural habitat. Roots for histological studies were preserved in $70 \%$ alcohol.

\section{Drying of plant material}

The root material of Calotropis gigantea (L.) R. Br. was subjected to shade drying for about 4 weeks. The shade dried material was further crushed to powder and the powder was passed through the mesh 22 and stored in air tight container for further analysis.

\section{Macroscopic and microscopic analysis Macroscopic study}

Macroscopic features were studied and photographs were taken with Nikon DSLR Camera (Plate 1). Macroscopic characters was studied with the help of floras (4). 


\section{Morphology}

Collected roots were observed carefully for its identical morphological characters. Morphological characters like colour, shape, size were noted down. Characters of roots were studied as per taxonomy (4) and measurement was taken by scale through naked eye.

\section{Microscopic analysis}

Microscopic examinations of plant studied were according to the standard method $(7,8)$. Transverse sections of root were prepared and stained with saffranin and fast green as per procedure. Same procedure was followed for powder microscopy $(9,10)$. The microphotographs were taken by bright field microscope with digital camera.

\section{Extraction of powdered plant drug}

The plant material collected from their natural habitat was cleaned, shade dried and stored in an airtight glass container. 100 gms. Of coarse powder was successively extracted with different solvents viz. Petroleum ether, chloroform, Methanol(40-60) and ethanol in soxhlet extractor for 16-18 hrs. Then the extracts were filtered and concentrated using rotator flash evaporator. Freshly prepared extracts were subjected to phytochemical evaluation and TLC analysis.

\section{Thin Layer chromatography}

TLC analysis was performed following standard method (12).

The method is used for separation of the natural products such as steroids, terpenes, alkaloids, and flavonoids present in the mixture and various solvent systems are used for this purpose (11).

\section{Result and discussion}

\section{Macroscopic and microscopic analysis}

It is an erect, much branched shrub, 1-5m high grown throughout India, abundantly in dry waste lands. , often branched Roots cylindrical, tortuos often branched, rough, fissured longitudinally, soft and corky, externally yellowish grey while internally creamish white in colour, bark easily separated from xylem. Roots are $0.5-2.0 \mathrm{~cm}$. in diameter bearing rootlets. Rootlets are varying diameter from $0.2-0.5 \mathrm{~cm}$. odour, characteristic: taste, bitter and acrid.

\section{Pharmacognostic Investigation}

The detailed and systematic pharmacognostical evaluation of Calotropis gigantea (L.)R. Br. would give valuable information for future studies. The detailed morphology of Calotropis gigantea (L.) R. Br. was carried out to support proper identification of the drug. Three samples of root are collected for microscopical studies. Histological features are found same in all the samples.

\section{Microscopy}

The transverse section of the root indicated the presence of cork as the outermost layer. The cork cells were regularly arranged with 15-20 layers of rectangular cells closely arranged without any intercellular space.
The cork region was highly lignified. The phellogen was indistinguishable.

\section{Cortex Region:}

The cells in the cortex region consisted of abundant number of starch grains. These cells were consisted of irregularly shaped parenchymatic cells closely arranged. Cells of both cortex and phloem contains laticiferous tubes and rossete of calcium oxalate. The parenchyma cortex were not lignified. The secondary region was well differentiated with 3-4 layers of phloem layer in between the cortex and the secondary region. Medullary ray was observed in the cortex region which extended into the secondary region.

\section{Secondary Region:}

Highly lignified cells with well developed xylem vessels, xylem fibres, xylem parenchyma cells. Medullary rays extended till the middle. These medullary rays were 1-3 cell broad with starch grains present in them. The total length of TS varied from 340$460 \mu$ long with cork region of $50-80 \mu$ long, cortex region of $60-130 \mu$ long, and secondary region of 230 $250 \mu$ long.

\section{Result of Powder Microscopy:}

Colour- Powdered drug was off white to yellowish white in colour.

Following characters were observed in the powder:Cork cells: multi layered lignified cells were observed. Ca Oxalate crystals: Prism type of crystals was observed when the powder was treated with acetic acid. Starch grains: Powdered drug when treated with iodine and observed showed simple and compound type of starch grain. The size of the starch grain varied from $20-40 \mu$. Xylem vessels: lignified pitted xylem vessels were observed. The fibres were simple, thin walled with 180 $200 \mu$ length and 20-30 $\mu$ wide.

\section{Preliminary Phytochemical Analysis:}

Preliminary phytochemical analysis of the Calotropis gigantea (L.) R. Br. plant root powder extract showed the presence of tannins, flavonoids, triterpenoides and alkaloids.

Table 1:Phytochemical constituent in Calotropis gigantea $(\mathrm{L}.) \mathrm{R}$. Br. plant root

\begin{tabular}{|l|l|l|}
\hline Sl. no. & $\begin{array}{l}\text { Class } \\
\text { Compounds }\end{array}$ & Test performed \\
\hline 1. & Alkaloids + & Dragendorf's test. \\
\hline 2. & Glycocides + & Keller killiani test. \\
\hline 3. & Tannins + & Ferric chloride test. \\
\hline 4. & Flavanoides + & Ammonia test. \\
\hline 5. & Steroides + & $\begin{array}{l}\text { Burchard-Liebermann } \\
\text { test. }\end{array}$ \\
\hline
\end{tabular}


Alarka (Root)

Calotropis gigantea (L.) R.Br Macroscopic characters

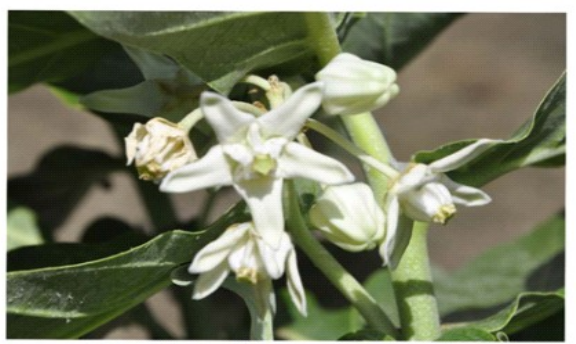

Plant

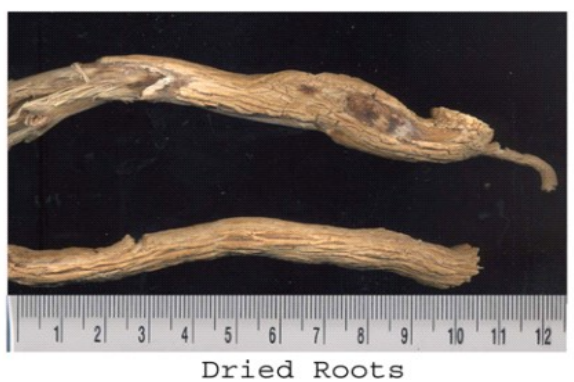

Fig 1:Macroscopic characters of the plant

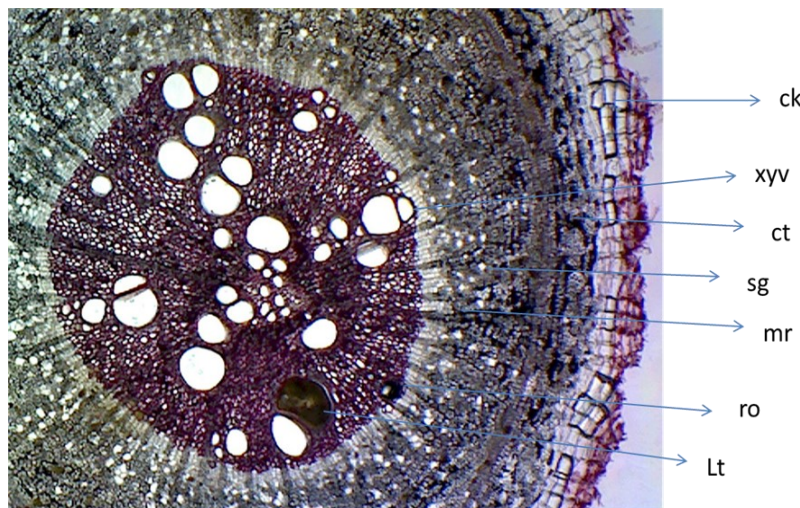

Fig A: T.S. of Root of Calotropis gigantea at $4 \mathrm{x}$

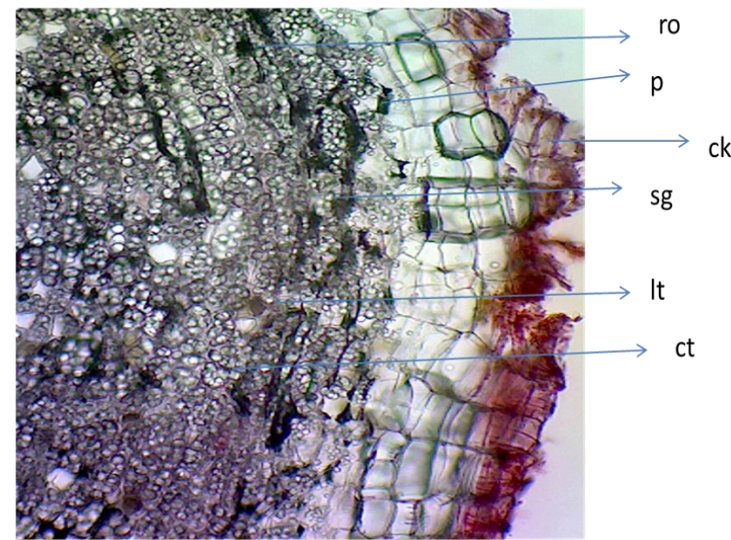

Fig2A: T.S. of Root of Calotropis gigantea cortical part at 10x showing abundant starch grains.

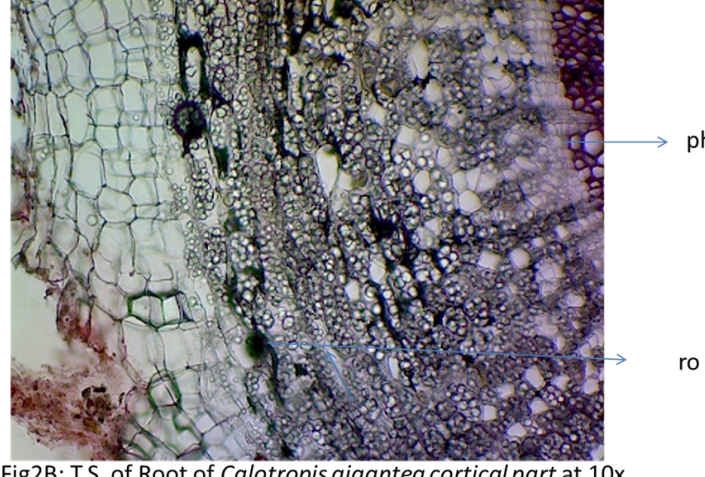

Fig2B: T.S. of Root of Calotropis gigantea cortical part at 10x showing rosette shaped calcium oxalate crystals.

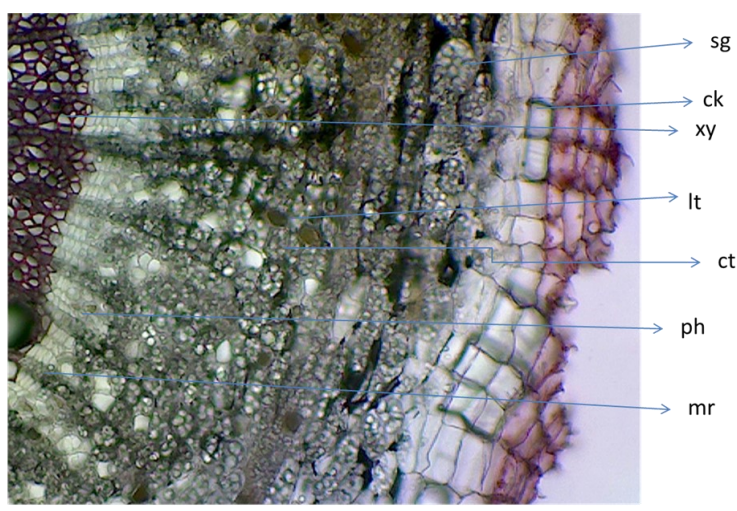

$\mathrm{F}$ ig2C: cortical part at $10 \mathrm{x}$ showing laticiferous ducts. T.S. of Root of Calotropis gigantea

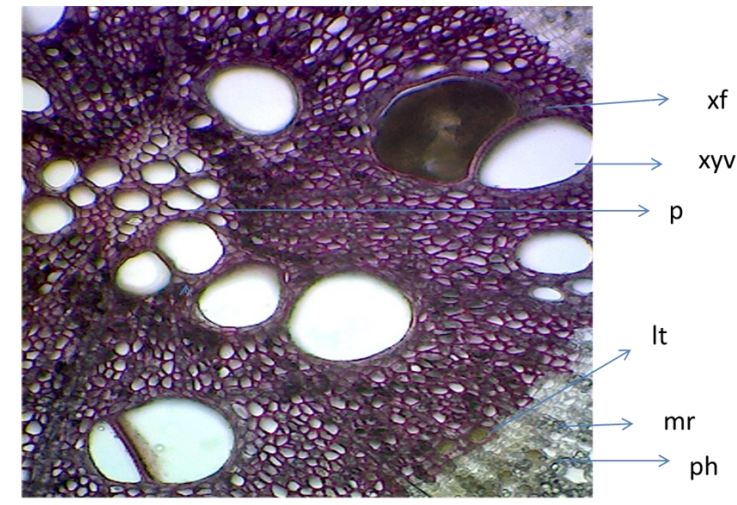

Fig2D: T.S. of Root of Calotropis gigantea at 10x showing secondary region

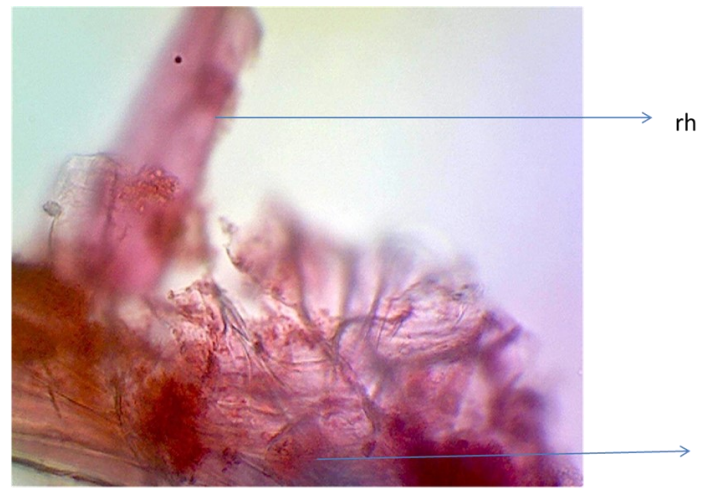

Fig3A: T.S. of Root of Calotropis gigantea at 40x showing root hair\& epidermal layer. 


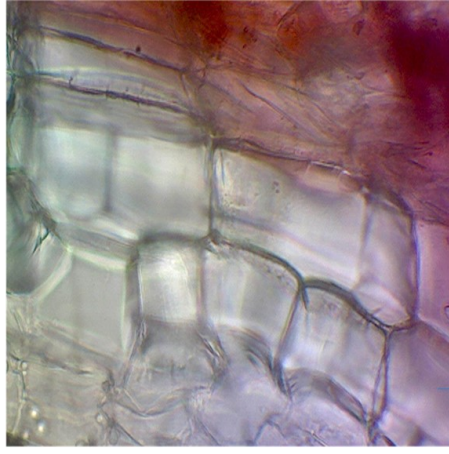

Fig3B: T.S. of Root of Calotropis gigantea at 40x showing cortical layer.

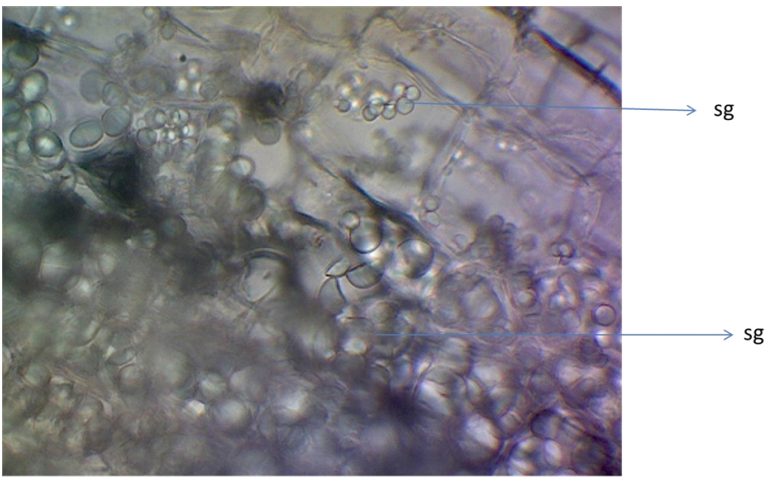

Fig3C: T.S. of Root of Calotropis gigantea at $40 x$ showing starch grains in cortical region.
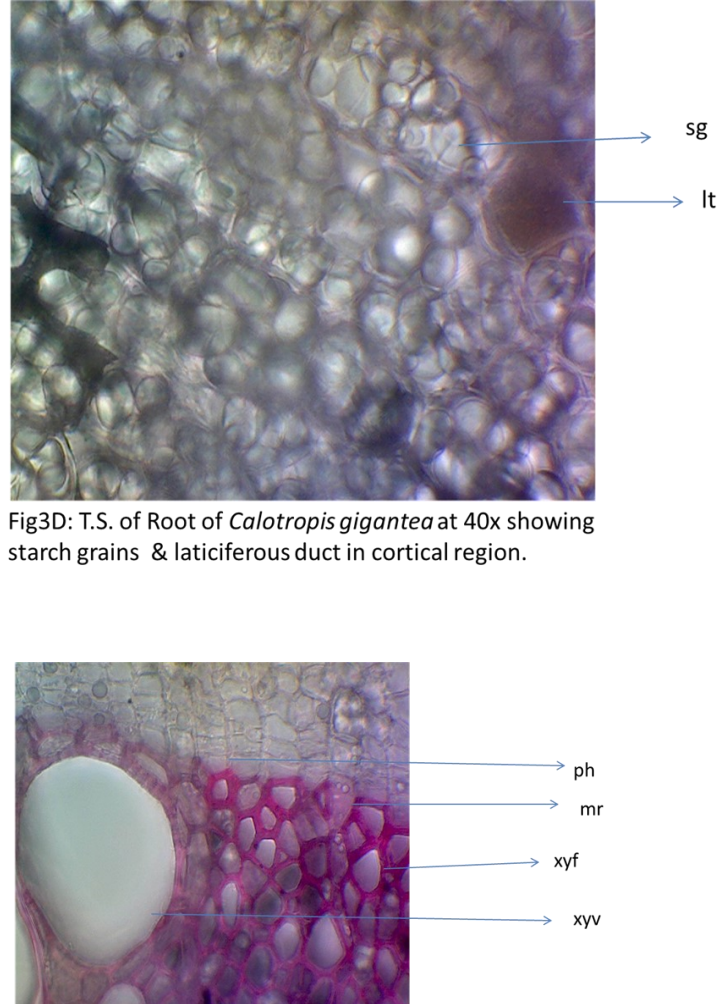

TS of Calotropis gigantea root fig A.4x fig2A-2D10x, fig 3A-3E 40x, ck, cork; ct, cortex;ed, epidermal layer; It, laticiferous tubes; $\mathrm{mr}$, medullary rays, $\mathrm{p}$, prism; $\mathrm{ph}$, phloem; ro, rosettes of calcium oxalate; rh, root hair; $s g$, starch grains; $x y, x y l e m ; x y f, x y l e m$ fibres; $x y v$, xylem vessels.

Fig 4: Powder Microscopy of Calotropis gigantean (L.) R. Br. Root.

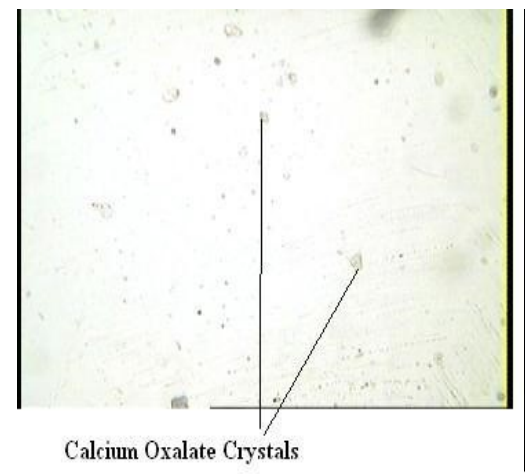

(Powdered drug treated with acetic acid)

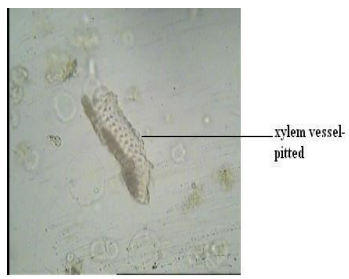

Xylen vessels in pordered dur

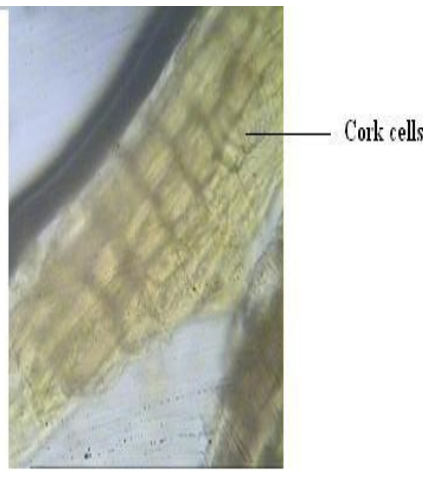

Liguified Cork- $450 \mathrm{x}$

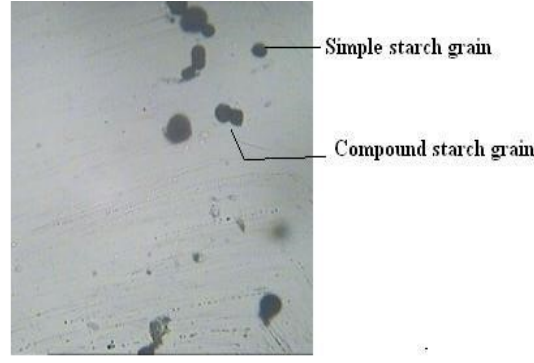

Powdered drug treated with iodine solution for identification of starch grains

Powder microscopy of calotropis gigantea (L.) R.Br. Root. 
Fig 5: Thin Layer Chromatography(12):

TLC analysis was performed following standard method (12) TLC analysis showed following result:

\author{
Sample: Methanol extract \\ Solvent system: Chloroform : Methanol (6:4) \\ Volume of test solution applied: $4.0 \mu \mathrm{l}$ \\ Distance travelled by solvent system: $80.0 \mathrm{~mm}$
}
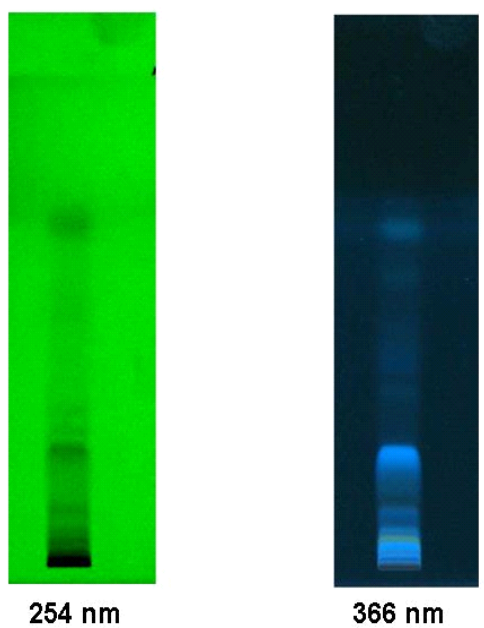

UV $254 \mathrm{~nm}$ - Developed plate when observed under $254 \mathrm{~nm}$ showed the following spots with Rf of - $0.03,0.09,0.30$ and 0.70 (All balck colour)

366nm:- Developed plate when observed under UV produced the following spots with $\mathrm{Rf}$ of $-0.03,0.09,0.30$ and 0.70 (blue )

\section{Conclusion:}

The plant with many curative principles and other economic values growing in all types of soil, climate etc. In this way its pharmacognostical standardisation and phytochemical analysis are very important to establish the uses of the plant more effectively.

In present investigation, various standardized parameters such as macroscopic, microscopic, pharmacognostic, phytochemical and TLC screening was carried out and which could be helpful in authentication of Calotropis gigantea (L.)R. Br. The result of present study will also serve the reference material in prepration of monograph. The plant is commoly found as a wasteland weed. Its many uses are described in Ayurvedic texts with calotopis procera L. Therefore present study may help to pharmaceutical industries as well as researchers.

\section{References:}

1) Sushruta Samhita of sushrutacharya with ayurvedatatvasandipika Hindi commentry, Shastri A. D. , Chaukhambha Sanskrit sansthan, Varanasi, 1953-1959.
2) Bhavaprakasha of Bhavamishra with Hindi Commentary by Bhisagratna Mishra B. S. , Chaukhambha Sanskrit Sansthan, $5^{\text {th }}$ Ed. 1980.

3) Kirtikar KR and Basu BD. Indian medicinal plants. $2^{\text {nd }}$ Edition, Bishen Singh Mahendra pal Singh, Dehradun 1980.

4) Mudgal et al Flora M. P. Botanical Survey of India Calcutta, Ed. 1997

5) Deshmukh et al, Wound healing activity of Calotropis gigantea root bark in rats, Journal of Ethnopharmacology 125 (2009) 178-181.

6) Anonymous. The Wealth of India. A dictionary of Indian raw materials and industrial products, New delhi, Publication and Information Directorate CSIR. 1988.

7) Evans WC. Trease and Evans Pharrmacognosy, WB Saunders Ltd. London. 2002.

8) Wallis TE. Textbook of Pharmacognosy. Published by SK Jain. 1985

9) Khandelwal KR. Practical Pharmacognosy. $18^{\text {th }}$ Edn. Nirali Prakashan, Pune. 2007.

10) Khasim SM. Botanical Microtechnique: Principles \& Practice. Capital Publishing Company, New Delhi. 2002.

11) Kokate CK. Preliminary phytochemical screening. In $4^{\text {th }}$ Edn. Practical Pharmacognosy. Nirali Prakashan, Pune, India 2000.

12) Anonymous, Ayurvedic Pharmacopoeia of India part-2, Vol. 3 appendix 2. 2. $101^{\text {st }}$ Edition 2010 govt. of India Publication.

13) Suresh Kumar P, Suresh. E, S. Kalavathy, Review on a potential herb Calotropis gigantea (L.)R. Br. Scholars Academic Journal of Pharmacy. , 2013;2(2):135-143

14) Ashraful MA , HabibMR, Nikkon F , Khalequzzaman $M$ and Karim MR; Insecticidal Activity of Root Bark of Calotropis gigantea L. against Tribolium castaneum(Herbst), World Journal of Zoology, 2009, 4(2): 90-95.

15) Gamble JS; Flora of the Presidency of Madras, Vol. 1, 2, 3, Botanical Survey of India, Calcutta, 1935.

16) Ahmed M, Rana, ACand Dixit VK; Plant Review Calotropis species (Asclepiadaceae): A comprehensive review, Pharmacognosy Magazine, 2005; (2): 48-52.

17) Pereira $\mathrm{W}$ and Seabrook J; Asking the Earth the spread of unsustainable development, Second impression the other India Press, GoaIndian Mapusa, 1996; 403-507.

18) Sharad Srivastava, Adarsh pratap Singh, A. K. S. Rawat Comparative botanical phytochemical evaluation of Calolotropis procera Linn. and Calotropis gigantea Linn. Root, Journal of applied Pharmaceutical science Vol. 5(07), pp. 041-047, July, 2015 